\title{
Research on Business Model Innovation Driven by Scientific and Technological Innovation*
}

\author{
Yanxia Cheng \\ School of Management \\ Wuhan University of Technology \\ Wuhan, China
}

\author{
Tianbao Liang \\ School of Management \\ Wuhan University of Technology \\ Wuhan, China
}

\author{
Jingjing Li \\ School of Management \\ Wuhan University of Technology \\ Wuhan, China
}

\begin{abstract}
The innovation of business model driven by science and technology has become one of the key drivers to promote the leap-forward growth of economy. Through literature review, this paper analyzes the theory of scientific and technological innovation to drive the business model innovation logic, summarizes the Internet age, the age of the Internet, and before the typical business model intelligent era, in order to grasp the future direction of the business model innovation for the enterprise, make the management decision to provide corresponding theoretical reference.
\end{abstract}

Keywords-scientific and technological innovation; business model innovation; platform mode; sharing economy; entrepreneurship

\section{INTRODUCTION}

Innovation-driven development strategy has become the core of China's development strategy. Theoretical research and practice prove that the innovation of business model is a change that has both the hypothesis and the thinking set of the industry [1]. In recent years, the innovation of business model has emerged, and the result of scientific and technological innovation and its transformation and application have played an indispensable role in it. Therefore, to clarify the theoretical logic of technological innovation to drive the innovation of business model and to predict the trend of business model innovation, it has the reference value and guiding significance for enterprises to advance the business model in advance.

\section{THE THEORETICAL LOGIC OF TECHNOLOGICAL} INNOVATION DRIVES THE INNOVATION OF BUSINESS MODEL

\section{A. Theoretical Review of the Innovative Driving Business Model of Science and Technology}

Compared with the general and mature technology innovation theory, the research on business model innovation is still in the process of perfection. Most scholars analyze the

*Thanks to the soft science project of the technical innovation project of Hubei province, China (2016ADC005). business model from the perspective of origin and process. McGrath believes that business model innovation is driven by external drivers [2]. From a dynamic perspective, this view defines the business model innovation as a result of "trial - trial and error - adjustment", which is a passive stress change process. Martins et al. thinks that business model innovation is driven by enterprises, and believes that the business model innovation begins with the cognition of the enterprise executive team [3]. From the perspectives of innovation process and Lecocq, etc. that business model innovation process is caused by internal factors of enterprise target, operation mode and profit mode [4], system evolution and the fundamental change. The research of Bucherer etc. showed that the so-called business model innovation is the enterprise change the key core elements for a specific purpose and business logic to achieve sustained profitability, is to design the process of operating model and profit model [5]. In conclusion, it is widely believed that business model innovation requires the participation and cooperation of enterprise internal and external value network members. Innovation is driven by internal factors such as enterprise management cognition, core competence, decisionmaking and other internal factors such as technological innovation, dynamic situation and market opportunity. It is a systematic change in the implementation of business model elements within the enterprise.

In the research on the innovation of science and technology innovation-driven business model innovation, the research literature on the technological innovation that drives the business model is rich. Wu xiaobo et al. (2013) scholars believe that there is a relationship between technological innovation and business model innovation. In addition, some scholars compare the business model innovation and the innovation of technology innovation process and innovation as a result, think both innovations based on the resources and capacity, to make scientific decision in order to get the final customer value and economic benefits. The innovation of enterprise technology innovation and business model has the consistency of process form and goal consistency. But there is an essential difference between Science and technology 
innovation and technological innovation. Science and technology innovation including knowledge innovation, technology innovation and management innovation from three aspects, scientific and technological level in different periods, different stages of development, the connotation and extension of science and technology innovation might be different, but the innovation system of the three elements of architecture is constant.

\section{B. Scientific and Technological Innovation Drives Business Model Innovation in Logic Analysis}

Science and technological innovation is different from technological innovation. The innovation of science and technology is mainly reflected in the innovation at the industrial and national level, while the technological innovation mainly involves the enterprise level. The transformation of scientific and technological innovation can not only bring about the customer value and economic benefits of technological innovation, but also create social welfare including scientific discovery and spiritual value. Therefore, compared with technological innovation, the internal logic of innovation driving business model is more complex and richer.

The research results of innovation-driven theory show that science and technological innovation brings technological innovation, knowledge innovation and management innovation, which greatly changes the external environment of enterprise operation. First, technical innovation as the optimization of industrial structure and economic growth mode transformation possible, resulting in earnings growth, and the emergence of more technology to improve the quality of workers, and using a series of positive, promote the enterprise's internal resource allocation optimization and ability level. Management innovation requires companies to break the original boundary, looking for a new source of innovation, forcing the enterprise structure and the way they operate more open and inclusive, and determines whether the enterprise can carry on the business model innovation effective. Second, management innovation and technology innovation can improve the efficiency of enterprise's internal operations and marketing, which changes the enterprise value creation logic, value delivery and access; create enterprise value creation and innovation of the profit model. At the same time, the organization form of enterprises under the impetus of the scientific and technological innovation platform and intelligent, achievements drops and other matching supply and demand model platform supply diversification of enterprise value and profit model innovation.

\section{ANALYSIS OF TYPICAL BUSINESS MODEL DRIVEN BY TECHNOLOGY INNOVATION}

With the development of science and technology, the role of various stakeholders in the value chain has gradually changed. Industrialized era carrier of enterprise business model transfer customer value proposition is a linear, one-way flow of value chain, along with the science and technology innovation, the traditional linear and unidirectional value chain to the value of dynamic, interactive network and the evolution of business ecosystem.

\section{A. Business Model of Information Age}

1) The business model driven by technological innovation in the pre-internet era

a) Industrial chain perspective: Information technology promotes the rapid development of traditional enterprises and information enterprises, and promotes the continuous extension of the traditional industrial chain and the closer links between upstream and downstream enterprises. Due to the frequent sharing of database information and interaction between industries, it has also strengthened mutual cooperation and formed inter-industry strategic alliance. In this stage, enterprise competition evolves into supply chain competition. Therefore, the value transfer and value creation of most enterprise business models in this period cannot be separated from the collaboration of upstream and downstream industry chain.

\section{b) Strategic perspective}

\section{- Mass customization mode}

Information technology promotes the rapid development of traditional enterprises and information enterprises, and promotes the continuous extension of the traditional industrial chain and the closer links between upstream and downstream enterprises. Due to the frequent sharing of database information and interaction between industries, it has also strengthened mutual cooperation and formed inter-industry strategic alliance. In this stage, enterprise competition evolves into supply chain competition. Therefore, the value transfer and value creation of most enterprise business models in this period cannot be separated from the collaboration of upstream and downstream industry chain.

\section{- Physical platform mode}

Because of technological innovation, electronic digital technology has achieved the use of digitization to capture sound, and the enterprise has designed the technology physical carrier for the interaction and exchange of the two parties. The carrier is the prototype of the platform mode, which connects the supplier with the buyer through the hardware platform, and the value proposition extends from one way to the two-way. The typical representative is apple's iPod.

\section{- Likey mode (precision product mode)}

The application of standardization and service robots and the popularization of RFID technology provide technical guarantee for the change of enterprise value creation process. Companies aim at niche markets where products are small, refined and diverse. The combination of small and multicategory products makes for diverse and low-cost value propositions.

2) The business model driven by technological innovation in the Internet age: Since the 1980s, with the maturity of Internet related technologies, such as communication technology and IT system, the penetration and integration of manufacturing, finance, logistics and other industries have been full. The penetration and embedding of Internet information technology into industries, agriculture and service 
industries have led to the blurring of industrial boundaries, deepening the integration of services and manufacturing industries. In this stage, the consumption concept has taken a qualitative leap and experiential consumption and personalized consumption has gradually become main stream, and the value creation process pays more attention to coworking with upstream and downstream enterprises to create customer value. The profit model emphasizes the customer's whole scene profit digging. At this stage, a series of new business models emerged.

a) Free mode: Free pattern as representative business model, in this stage mainly refers to rely on the accumulation of free customer resources, at the same time there are other customer segment willing to pay, offer free customer segmentation group financial support; By establishing the user's trust relationship, it can reduce the cost of re-contacting the customer and realize additional value-added profit. It is divided into: first, bilateral, multilateral free, third-party payment (advertising and other), online traffic liquidity logic. Second, basic services are free and premium services. Third, the fishing mode relies on free accumulation of customer resources to cultivate customer habits, and then attract customers to repeat the purchase of follow-up products.

b) Platform mode: Platform mode is the most important innovation of this stage of business model. The model by network effects and entity platform connecting different communities, transfer the value chain benefit related parties and even the final consumers to actively participate in, to innovation value proposition, value creation and realization. The typical platform model is the multilateral resource integration platform. Specific include: first, supply and demand matching platform mode. For example, the supply and demand matching platform created by didi travel. Second, the supply side shortage resource classification matching mode. Through the establishment of grading platform, the supply side scarce resources should be cut. Third, multilateral sharing creates a platform model. In a new generation of information technology, driven by innovative undertaking public (including enterprises and individuals) according to the requirement from innovation platform, using the platform provides powerful tool for sharing research and development and production, turn their own ideas and thoughts into physical products and solutions. Fourth, the demand side sharing platform model. Using the new Internet technology to develop a Shared platform, we can provide a Shared platform and carrier for the demand side by the maturity and popularization of the scanning code and online payment technology. c) Internet + industrial chain integration mode: Internet + industry chain integration model is the new stage of the innovation of business model in the Internet era. The model uses a new generation of information technology and Internet technology, enterprises through the adjustment and optimization of the industrial chain link the relationship between the relevant enterprises, and make them work together, improve the operation efficiency of the whole industry chain, extending the original value proposition. The characteristics of this model are: through forward integration and backward integration, the traditional industrial chain upstream and downstream.

3) The business model driven by scientific and technological innovation: As the data mining technology, the emergence of intelligent software, intelligent interactive technology, and the traditional industry value creation pattern is broken, under the traditional mode of production, enterprises are producers, and users are consumers, clear boundaries. With the popularization and application of sharing platform technology, customers are more involved in the production activities of enterprises from simple consumers. Using intelligent terminal and interactive technology, Internet technology, sharing platform technology and system integration system, share information and achieve high participation of all subjects. The typical business model of this stage includes: first, intelligent Shared co-create platform mode, such as Skill share launch is a similar self-service education sharing platform. Second, personalized network push based on big data. Amazon has launched a new feature called "My Mix", which is designed to recommend products that may be popular based on the consumer's personal needs. Third, the smart retail industry, including small community retail business and retail industry.

a) Industrial chain perspective: Information technology promotes the rapid development of traditional enterprises and information enterprises, and promotes the continuous extension of the traditional industrial chain and the closer links between upstream and downstream enterprises. Due to the frequent sharing of database information and interaction between industries, it has also strengthened mutual cooperation and formed inter-industry strategic alliance. In this stage, enterprise competition evolves into supply chain competition. Therefore, the value transfer and value creation of most enterprise business models in this period cannot be separated from the collaboration of upstream and downstream industry chain in "Table I".

TABLE I. FEATURES AND TYPICAL BUSINESS MODELS OF TECHNOLOGICAL INNOVATION

\begin{tabular}{|l|l|l|l|}
\hline $\begin{array}{c}\text { The phase of the } \\
\text { development of science } \\
\text { and technology }\end{array}$ & \multicolumn{2}{|c|}{ The information era } & Pre-intelligent age \\
\hline time & Computer age (1950s) & Internet age (2015) & At the beginning of the 21st century \\
\hline $\begin{array}{l}\text { Science and technology } \\
\text { innovation }\end{array}$ & $\begin{array}{l}\text { The advent of electronic } \\
\text { computers } \\
\text { Information technology (it) }\end{array}$ & $\begin{array}{l}\text { Internet related technologies such as system integration and } \\
\text { communication technology mature }\end{array}$ & $\begin{array}{l}\text { Robot, artificial intelligence, automation } \\
\text { production line, Internet of things, big } \\
\text { data, cloud computing mature }\end{array}$ \\
\hline
\end{tabular}




\begin{tabular}{|c|c|c|c|}
\hline $\begin{array}{c}\text { The phase of the } \\
\text { development of science }\end{array}$ & \multicolumn{2}{|c|}{ The information era } & \multirow[t]{2}{*}{ Pre-intelligent age } \\
\hline Production mode & $\begin{array}{l}\text { Digital computer control } \\
\text { automation, automation line, } \\
\text { refined production }\end{array}$ & $\begin{array}{l}\text { To give full play to the optimized } \\
\text { integration of the Internet in } \\
\text { production factor allocation; It is } \\
\text { transformed from mass } \\
\text { homogenization to on-demand } \\
\text { manufacturing, flexibility, and agile } \\
\text { manufacturing }\end{array}$ & \\
\hline $\begin{array}{l}\text { Characteristics of the } \\
\text { consumer demand }\end{array}$ & $\begin{array}{l}\text { Convenient consumption, the } \\
\text { quality, function } \\
\text { requirements and attention of } \\
\text { different kinds of perceptual } \\
\text { consumption, experiential } \\
\text { consumption, } \\
\text { consumption and consumer } \\
\text { demand for private users } \\
\text { from pure consumers more } \\
\text { and more involved in the } \\
\text { enterprise production } \\
\begin{array}{l}\text { activities to produce } \\
\text { disappear }\end{array}\end{array}$ & $\begin{array}{l}\text { Emotional consumption, experience } \\
\text { consumption, green consumption, } \\
\text { consumer demand personal }\end{array}$ & $\begin{array}{l}\text { The user from the simple consumer } \\
\text { more and more participates in the } \\
\text { enterprise production activity, becomes } \\
\text { the producer }\end{array}$ \\
\hline Value proposition & $\begin{array}{lr}\text { Meet quality, function to } \\
\text { differentiation } & \text { and } \\
\text { personalized } & \text { demand } \\
\text { transformation; } & \text { Enterprise } \\
\text { boundary clarity } & \end{array}$ & $\begin{array}{l}\text { Emphasizing the supply of } \\
\text { diversified value and providing } \\
\text { comprehensive solutions; Corporate } \\
\text { boundaries blur }\end{array}$ & $\begin{array}{lcc}\text { Customers } & \text { participate in design, } \\
\text { production and customer } & \text { design and } \\
\text { production. } & \text { Industrial } \\
\text { ambiguity } & & \text { boundary } \\
& \end{array}$ \\
\hline Value creation & $\begin{array}{l}\text { Relying on their own } \\
\text { resource endowment and } \\
\text { autonomous operation } \\
\text { organization, lack of value } \\
\text { network expansion, no } \\
\text { resource coordination }\end{array}$ & $\begin{array}{l}\text { Based on the development trend of } \\
\text { the industry, the efficient operation } \\
\text { form and organization form } \\
\text { surrounding the key resources } \\
\text { should be focused on the } \\
\text { cooperation of upstream and } \\
\text { downstream enterprises to create } \\
\text { customer value }\end{array}$ & $\begin{array}{l}\text { Using intelligent terminal and } \\
\text { interactive technology, Internet } \\
\text { technology, sharing platform technology } \\
\text { and system integration system, sharing } \\
\text { information, efficient collaboration, and } \\
\text { co-creating value with customers }\end{array}$ \\
\hline $\begin{array}{l}\text { A typical commercial } \\
\text { model }\end{array}$ & $\begin{array}{l}\text { Mass customization and } \\
\text { modular production mode; } \\
\text { Physical platform mode; The } \\
\text { legislative mode }\end{array}$ & $\begin{array}{l}\text { Free mode; Platform mode; Internet } \\
\text { + industry chain integration model }\end{array}$ & $\begin{array}{l}\text { Intelligent sharing co-create platform } \\
\text { mode; Industrial chain o2o model; } \\
\text { Smart retail formats; Personalized } \\
\text { network push based on big data. }\end{array}$ \\
\hline $\begin{array}{l}\text { Representative } \\
\text { enterprise }\end{array}$ & $\begin{array}{l}\text { Toyota, MOTOROLA, } \\
\text { SONY, Microsoft, IBM; } \\
\text { Hanall clothing, gree, haier, } \\
\text { wushang, carvings }\end{array}$ & $\begin{array}{l}\text { Jingdong, WeChat, } 360,58 \text {, uber, } \\
\text { mobai and other Shared cycling } \\
\text { trips, didi sharing trips }\end{array}$ & $\begin{array}{l}\text { Skillshare education sharing platform; } \\
\text { Shangpin housing (smart home); } \\
\text { Amazon "My Mix"; Unmanned shelves } \\
\text { and smart community supermarkets }\end{array}$ \\
\hline
\end{tabular}

\section{CONCLUSION}

Knowledge innovation, technological innovation and technology-oriented management innovation brought by science and technology innovation lay the technical foundation for the innovation of enterprise business model. The policy environment, external competitive pressure and entrepreneurial innovation spirit within enterprises play a key role in the innovation of technological innovation. Business model from single line value delivery mode to industrial chain collaboration platform, then to share and intelligent co-create mode, evolve continuously.

The dynamics of market and the objective law of scientific and technological progress lead to the endless innovation of business model. With the further development of a new generation of information technology, integrated innovation (holistic innovation) will become mainstream, strategic perspective of a comprehensive innovation and collaborative innovation, will drive the future business model may be the Internet + across industry ecological mode and intelligent as the core of artificial intelligence applied business models as the direction of evolution.

\section{REFERENCES}

[1] Bock A J, Opsahl T, George G, et al. The effects of culture and structure on strategic flexibility during business model innovation [J]. Journal of Management Studies, 2012, 49(2):279-305.

[2] Mcgrath R G. Business models: A discovery driven approach [J]. Long Range Planning, 2010, 43(2-3):247-261.

[3] Martins L L, Rindova V P, Greenbaum B E. Unlocking the hidden value of concepts: A cognitive approach to business model innovation [J]. Strategic Entrepreneurship Journal, 2015, 9(1):99-117.

[4] Lecocq X, Demil B, Ventura J. Business models as a research program in strategic management: An appraisal based on lakatos [J]. 2010, 13(4):214-225.

[5] Bucherer E, Eisert U, Gassmann O. Towards systematic business model innovation: Lessons from product innovation management [J]. Creativity and Innovation Management, 2012, 21(2):183-198. 